\title{
Introduction of a new species, the ferret (Mustela putorius furo), in pathomorphological diagnostics - 7 years of Croatian experience
}

\author{
Doroteja Huber ${ }^{1 *}$, Margarita Dvornik-Gojsalić², Branka Artuković1, \\ and Ana Beck ${ }^{1}$
}

${ }^{I}$ Department of Veterinary Pathology, Faculty of Veterinary Medicine, University of Zagreb, Zagreb, Croatia

${ }^{2}$ Faculty of Veterinary Medicine, University of Zagreb, Zagreb, Croatia, student

HUBER, D., M.DVORNIK-GOJSALIĆ, B. ARTUKOVIĆ, A. BECK: Introduction of a new species, the ferret (Mustela putorius furo), in pathomorphological diagnostics - 7 years of Croatian experience. Vet. arhiv 87, 317-331, 2017.

\section{ABSTRACT}

Since ferrets (Mustela putorius furo) were first introduced into Croatia as pets around 15 years ago, their popularity and number has risen continuously. This increase has been met by a concomitant need for additional veterinary diagnostic attention. We conducted a retrospective study of 14 cytological, 49 histopathological diagnoses and 5 morphological diagnoses made from samples obtained from 68 individuals of the Croatian ferret population over a 7 year period. Submitted samples originated from $60.7 \%$ male and $39.3 \%$ female animals, with an median age of 5.1 years, and an age range from 1 year to 9 years. All cases diagnosed at the Department of Veterinary Pathology Zagreb were classified as either neoplasms $(\mathrm{n}=37)$, inflammatory lesions $(\mathrm{n}=15)$, degenerative disorders $(n=5)$ or miscellaneous lesions $(n=11)$. The most sensitive ferret organ systems to injurious stimuli were the haemolymphatic system, the skin and the endocrine system. Neoplasia presented as the major type of injury to organs, with multicentric lymphoma being the leading diagnosis (diagnosed in 12 cases). Ferrets are still a relatively rare companion animal in Croatia, but the lesions described in our survey correspond to lesions in ferret populations in other countries.

Key words: ferret (Mustela putorius furo) pathology, neoplasia, inflammation, degenerative lesion, retrospective study

\section{Introduction}

Ferrets (Mustela putorius furo) are mammalian carnivores belonging to the family Mustelidae. In the wild, they are primarily solitary animals which are obligate carnivores (QUESENBERRY and CARPENTER, 2012). The ferret was first domesticated 3000 to 4000 years ago, approximately at the same time as the cat (Felis catus), for hunting lagomorphs

\footnotetext{
*Corresponding author:

Doroteja Huber, dr. med. vet., Faculty of Veterinary Medicine, University of Zagreb, Vjekoslava Heinzela 55, 10000 Zagreb, Croatia, Phone: +385 12390 310; E-mail: dhuber@vef.hr
} 


\section{Huber et al.: Introduction to ferret pathology - 7 years of the Croatian experience}

and rodent pest control (KEEBLE and MEREDITH, 2009; QUESENBERRY and CARPENTER, 2012). Nowadays, they have been adapted for laboratory research in the fields of virology, reproductive physiology, anatomy, endocrinology, and toxicology, but are mostly used as companions (QUESENBERRY and CARPENTER, 2012).

As companions, they are emotional, highly social, low-maintenance animals that function well with other ferrets and animals (QUESENBERRY and CARPENTER, 2012). Their mischievous and playful nature is retained into old age; additionally, they are cuddly, friendly and easily handled (KEEBLE and MEREDITH, 2009). Ferrets can be walked outside, but they must be held on a leash. Their lifespan in captivity is 5 to 10 years (KEEBLE and MEREDITH, 2009).

Ferrets were introduced to Croatia as companion animals at the beginning of the $21^{\text {st }}$ century. Since then, they have become increasingly popular. At the moment, there are no official estimates of the current population of ferrets in Croatia. In addition, there are no registered breeders, so ferrets can only be purchased in pet shops or from private breeding colonies. As the popularity and numbers of this species rise, ferrets are encountered more often in clinics, requiring veterinary attention. Croatian veterinarians, as well as diagnostic centers, must adapt to the increased demand of ferret owners for quality attention and care for their pets. For this purpose, an improved understanding is required of the naturally occurring diseases found in this species in Croatia, enabling comparisons with published data from other diagnostic centers worldwide. Like other companion animals, ferrets are susceptible to various infectious, neoplastic and endocrine diseases, and they also suffer from many degenerative disorders, such as heart disease and hydrometra (KEEBLE and MEREDITH, 2009; QUESENBERRY and CARPENTER, 2012). In addition, they can be affected by influenza strains which affect humans, and these viruses can be transmitted to humans, and vice versa (KEEBLE and MEREDITH, 2009).

No surveys on ferret diseases have been carried out in Croatia to date. In order to investigate and classify all submitted pathologic specimens and diagnoses derived from ferrets, and to determine the most common pathologies found in the Croatian ferret population, a retrospective survey was needed and performed.

\section{Materials and methods}

The archive of the Department of Veterinary Pathology, Faculty of Veterinary Medicine, University of Zagreb, was searched for the presence of ferret cytology, biopsy and necropsy reports and macro- and micro- photo documentation, dating from January 2009 to November 2015. The reports represented macroscopic and microscopic findings with final diagnosis in organs submitted for routine cytology, histopathology and necropsy from veterinary clinics throughout Croatia. Samples submitted for cytology were aspirates of altered organs stained by a May-Grünwald-Giemsa stain. Samples 


\section{Huber et al.: Introduction to ferret pathology - 7 years of the Croatian experience}

submitted for histopathology consisted of biopsy specimens dehydrated after fixation in $10 \%$ neutral buffered formalin, paraffin embedded, cut to a thickness of $5 \mu \mathrm{m}$ and stained with hematoxylin and eosin. We included all necropsy reports retrieved from ferret carcasses that were subjected to necropsy to determine the cause of progressive illness leading to lethal outcomes or euthanasia.

From the accompanying letter of every report, if available, age and gender information, as well as the organ of origin of the submitted samples were recorded. Regardless of sample type, all diagnoses were summarized and classified on the basis of the main aspects of the lesions in the tissue, such as neoplasms, inflammatory lesions and degenerative disorders. Diagnoses that did not fit into these categories were categorized as "miscellaneous lesion". If multiple samples were obtained from the same animal, they were discarded if the same organ was sampled and the diagnosis set was based on the same type of lesion, or the lesion was caused by the identical etiology. From lesions found during necropsy, only lesions directly related to the death of the animal or that were considered to be the reason for euthanasia of the animal were considered.

\section{Results}

In the investigation period of 7 years, 68 reports (14 cytology, 31 biopsy and 23 necropsy reports) originating from ferrets were included in the survey. Within necropsy reports, histological evaluation of organs and tissues was performed in 18 ferrets, while in five ferrets only the morphological diagnosis was available. The reports were classified into the following categories of lesions: neoplasms (37 cases), inflammatory lesions (15 cases), degenerative disorders (five cases) and miscellaneous lesions (11 cases) (Table 1).

Table 1. Presentation of age and gender distribution of investigated ferrets within classes of lesions

\begin{tabular}{|l|l|c|c|c|c|}
\hline \multicolumn{2}{|l|}{ Classes of lesion } & Neoplasia & Inflammation & Degeneration & Miscellaneous \\
\hline \multirow{2}{*}{ Number of cases } & $37(55 \%)$ & $15(22 \%)$ & $5(7 \%)$ & $11(16 \%)$ \\
\hline \multirow{2}{*}{ Gender } & Male & $16(43.2 \%)$ & $11(78.6 \%)$ & $4(100 \%)$ & $6(60 \%)$ \\
\cline { 2 - 6 } & Female & $17(56.8 \%)$ & $3(21.4 \%)$ & $0(0 \%)$ & $4(40 \%)$ \\
\hline \multirow{2}{*}{ Age } & Mean (years) & 5.4 & 4.1 & 7 & 5,7 \\
\cline { 2 - 6 } & Range (years) & $2-9$ & $1-7$ & $6-8$ & $3-9$ \\
\hline
\end{tabular}

The submitted samples originated mostly from male animals (Table 1). In seven cases, the gender of the ferret was unknown. The mean age of investigated ferrets was 5.1 years (range: one to nine years). Most samples originated from middle aged and geriatric individuals that were between four and seven years old. 


\section{Huber et al.: Introduction to ferret pathology - 7 years of the Croatian experience}

Neoplastic growth found in 37 cases was the most common lesion detected in Croatian ferrets. Neoplasms were found in equal numbers of male and female animals (Table 1). The mean age of affected ferrets was 5.4 years (Table 1). Most frequently the neoplasia was found in the haemolymphatic system (12 cases) and skin (11 cases).

All cases of haemolymphatic neoplasia (12 cases) were diagnosed as multicentric lymphoma (VALLI et al., 2016) (Fig. 1A and 1B). The mean age of ferrets suffering from lymphoma was 5.6 years (range: 2-8 years). A stage I multicentric lymphoma (VALLI et al., 2016) was diagnosed in six cases, while stage V lymphomas affecting the liver (VALLI et al., 2016; Fig. 1B), stomach, kidneys and/or adrenal glands were found in additional six cases.

The skin was found to be a common site for development of neoplasia within the investigated population of ferrets. Sebaceous gland epithelioma (5 cases; Fig. 1C), sebaceous gland adenocarcinoma ( 2 cases), sebaceous gland adenoma ( 1 case), basal cell carcinoma (1 case), mastocytoma (1 case; Fig. 1D) and undifferentiated malignant mesenchymal tumour ( 1 case) were diagnosed. The majority of affected ferrets suffering from skin neoplasia were female ( 8 cases, $80 \%$ ), while two males $(20 \%)$ developed skin neoplasm. In one case, the gender of the ferret was unknown. The mean age of dermatology-oncology patients among the investigated ferrets was 5.5 years (range 2-9 years). All skin regions of the body were equally represented regarding neoplastic growth (head, neck, trunk, abdomen and legs).

In the endocrine system, nine neoplasms of the adrenal gland and pancreas were found. Within the adrenal cortex, four adenocarcinomas and one adrenal cortex adenoma were found, while three islet cell tumours and one clinically confirmed insulinoma were diagnosed in the pancreas (Fig. 1E). Endocrine neoplasms were almost exclusively reported in males (6 cases, $85.7 \%)$. Only one female $(14.3 \%)$ was diagnosed with adrenal cortex adenoma. In two cases, the gender of the ferret was unknown. The mean age of the affected ferrets in this category was 5.3 years (range 3-7 years).

Other diagnosed neoplastic conditions consisted of single cases of neoplastic alteration in four different organs: biliary cystadenocarcinoma (Fig. 1F) and hemangiosarcoma (Fig. 2A) in the liver, peripheral nerve sheath tumour in the testicle (HOHŠTETER et al., 2012), granulosa cell tumour in the ovary and adenocarcinoma of the duodenum (Fig. 2B). The mean age of the affected ferrets in this group was 4 years (range: 3 to 7 years). These neoplasms were diagnosed equally in male and female animals ( 2 cases each).

Inflammation as the cause of tissue and organ destruction was found in 15 cases (11 male animals $(78.6 \%)$ and three female animals $(21.4 \%)$; in one case the gender was unknown) (Table 1). The mean age of the affected ferrets was 4.1 years (Table 1). 
D. Huber et al.: Introduction to ferret pathology - 7 years of the Croatian experience

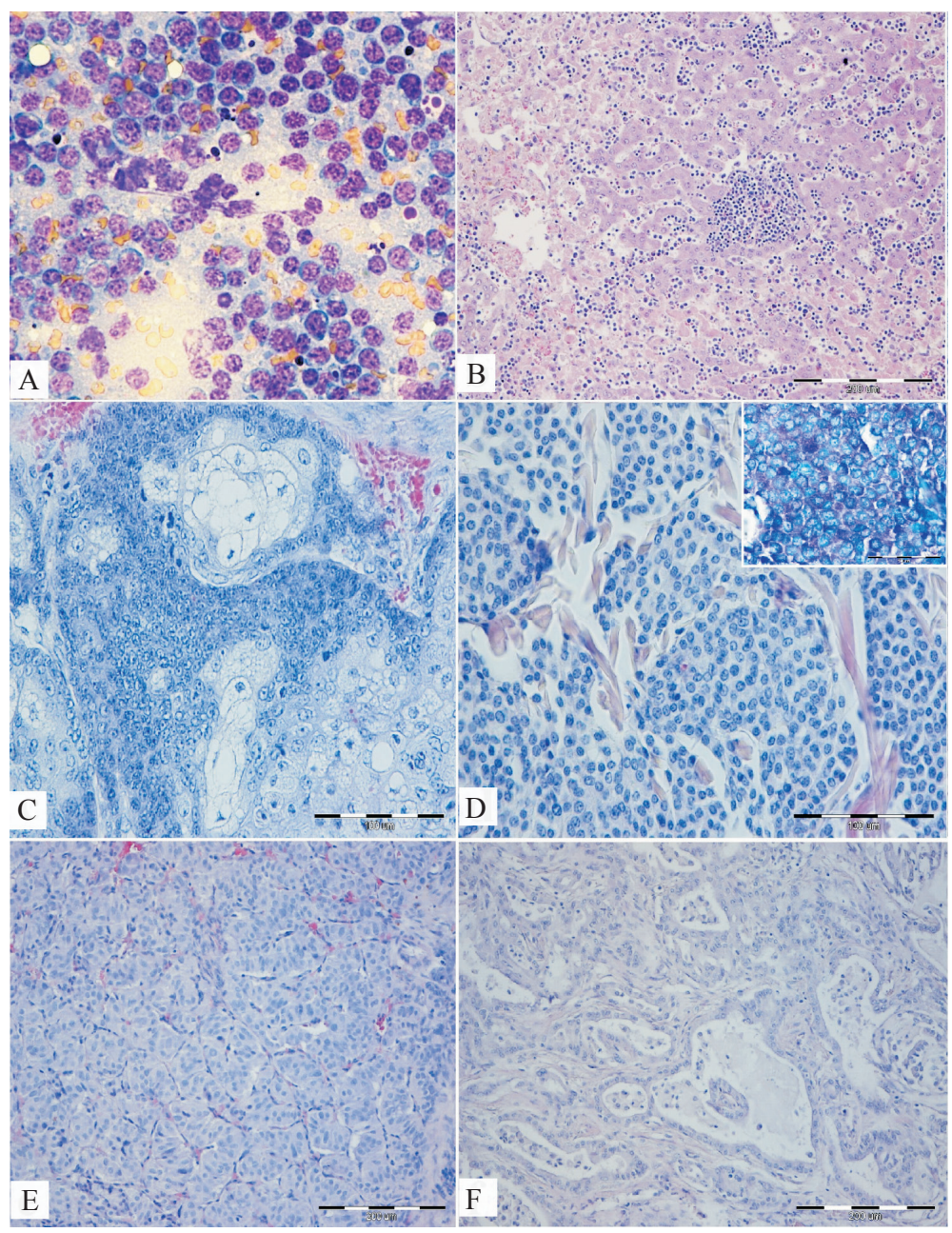

Fig. 1. Neoplasms. A. Aspirate of an enlarged subcutaneous lymph node. Lymphoma; homogenous cell population of large tumorous lymphoblasts. May-Grünwald-Giemsa stain (MGG), magnification $\times 400$; B: Liver with metastases of lymphoma. Distended sinusoids are filled with neoplastic cells. Hemalaun and eosin stain $(H \& E), \times 200$; C: Exophytic formation in the skin on the neck. Sebaceous gland epithelioma. H\&E, $\times 400$; D: Dermal nodules on the front and hind leg. Mastocytoma. H\&E, $\times 400$; Inset: Positive staining of mast cells with toluidin blue stain, 1000x. E: Pancreas, nests of cuboidal to columnar neoplastic cells separated by thin connective tissue septa replacing pancreatic tissue. Insulinoma. H\&E, $\times 200$; F: Liver. Biliary cystadenocarcinoma. H\&E, $\times 200$. 


\section{Huber et al.: Introduction to ferret pathology - 7 years of the Croatian experience}

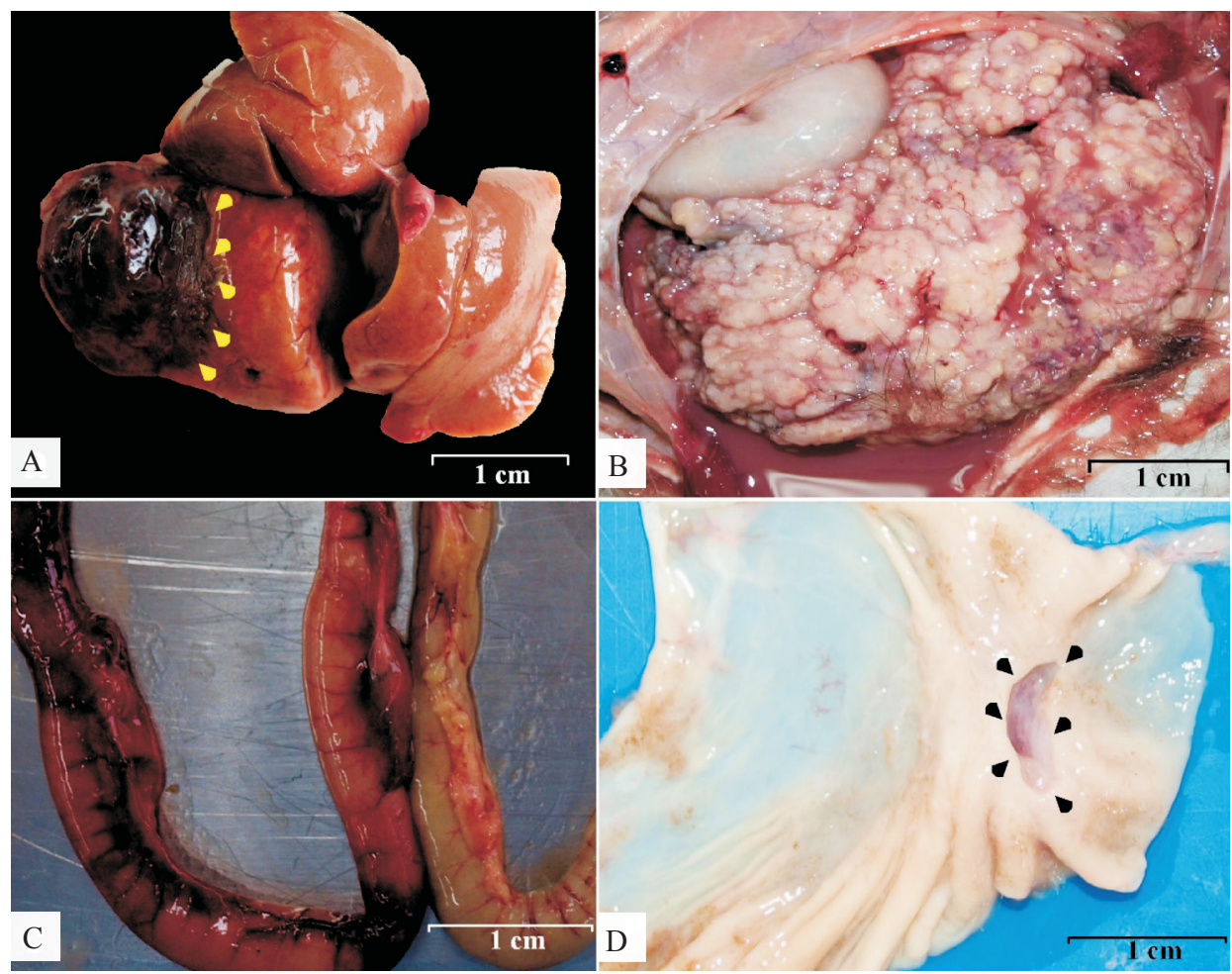

Fig. 2. Gross findings in selected cases. A: Liver. A hemangiosarcoma growing into the lobus hepatis dexter medialis (arrows). B: Abdominal cavity with hemorrhagic and suppurative peritonitis. Duodenum is replaced by an adenomatous, grey-yellow tumorous mass (adenocarcinoma). C: Jejunum. Hemorrhagic jejunitis of unknown cause (red colored jejunum on the left). Greenish-brown unaffected jejunum for comparison on the right; D: Stomach. Chronic ulcer in the pyloric area (arrows) caused by a foreign body (not shown).

The digestive system was the most common site of inflammatory process development, with the stomach as the most frequently affected organ. There were two cases of erosive gastritis and one case of ulcerative gastritis, all of unknown cause. Two additional cases of ulcerative gastritis developed due to foreign body ingestion (Fig. 2D), and chronic stress influence as progressive ulcerative gastritis with focal perforation and focal peritonitis development. In the particular case of gastritis caused by a foreign body, further ulcers and lymphocytic inflammation in the surrounding mucosa were found to be connected with a secondary infection by a mixed population of Gram-positive bacteria and bacterial organisms compatible with Sarcina sp. (Fig. 3A and 3B). 


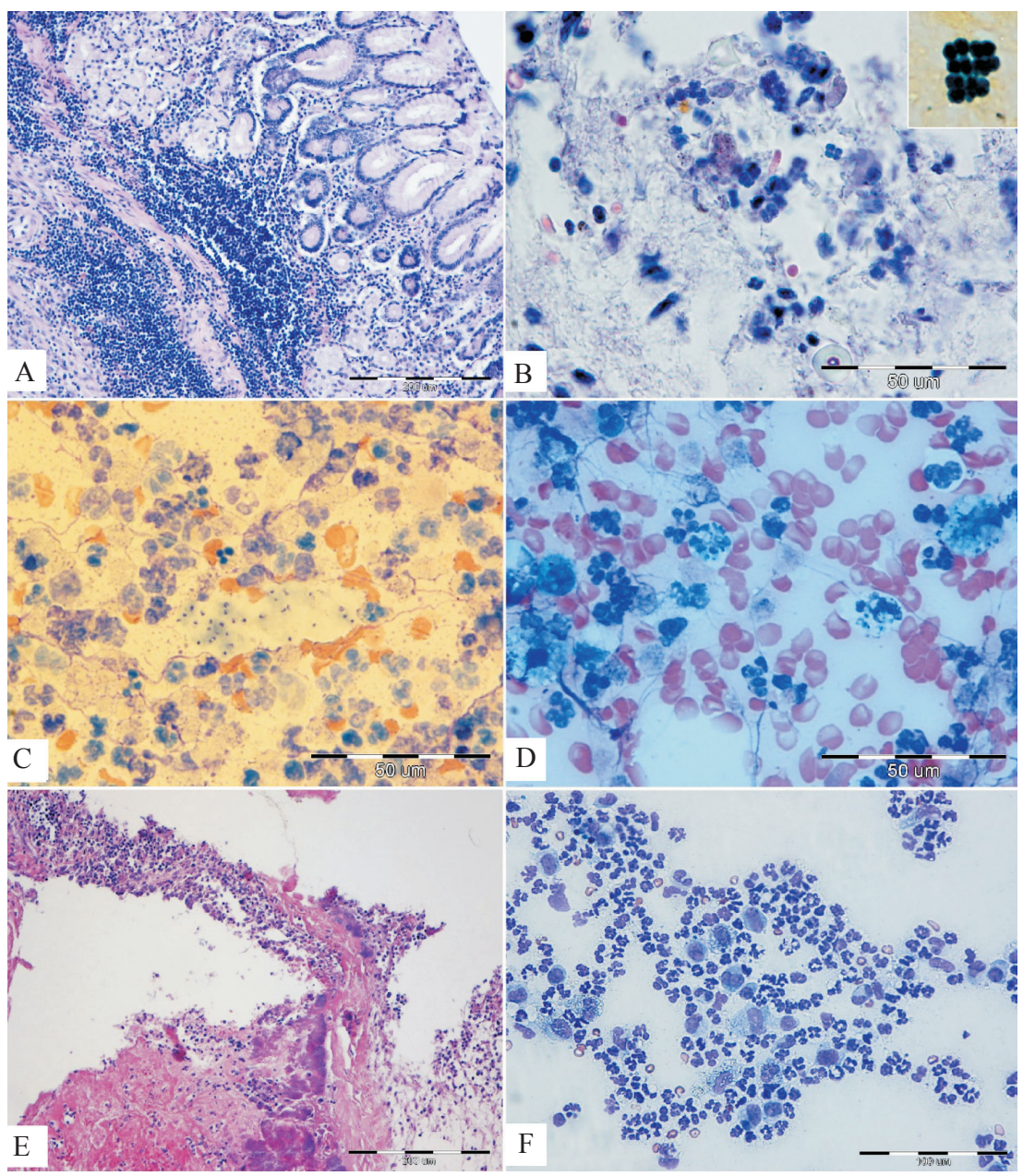

Fig. 3. Inflammatory disorders. A: Lymphocytic gastritis, caused by Sarcina-like bacteria. H\&E, $\times 200$; B: Same case as in Fig. 3 A. Colonization of gastric mucosa with numerous tetrad shaped bacteria morphologically suggestive of Sarcina sp. H\&E, $\times 1000$. Inset: Gram-positive staining of Sarcina sp. Gram-stain, $\times 1000$; C: Aspirate of a prescapular lymph node. Clusters of 1-2 $\mu \mathrm{m}$ rod-shaped Pseudomonas luteola with a bluish halo, surrounded by neutrophils and macrophages. MGG, $\times 1000$; D: Same case as in Fig. 3 C. Pyogranulomatous lymphadenitis with phagocytosis of $P$. luteola organisms. MGG, $\times 1000$; E: Bicuspidal valves. Fibrinous and purulent endocarditis with Gram-positive bacterial colonization of the valves. H\&E, $\times 200$. F: Aspirate of a subcutaneous mass. Pyogranuloma of the skin. MGG, $\times 400$ 

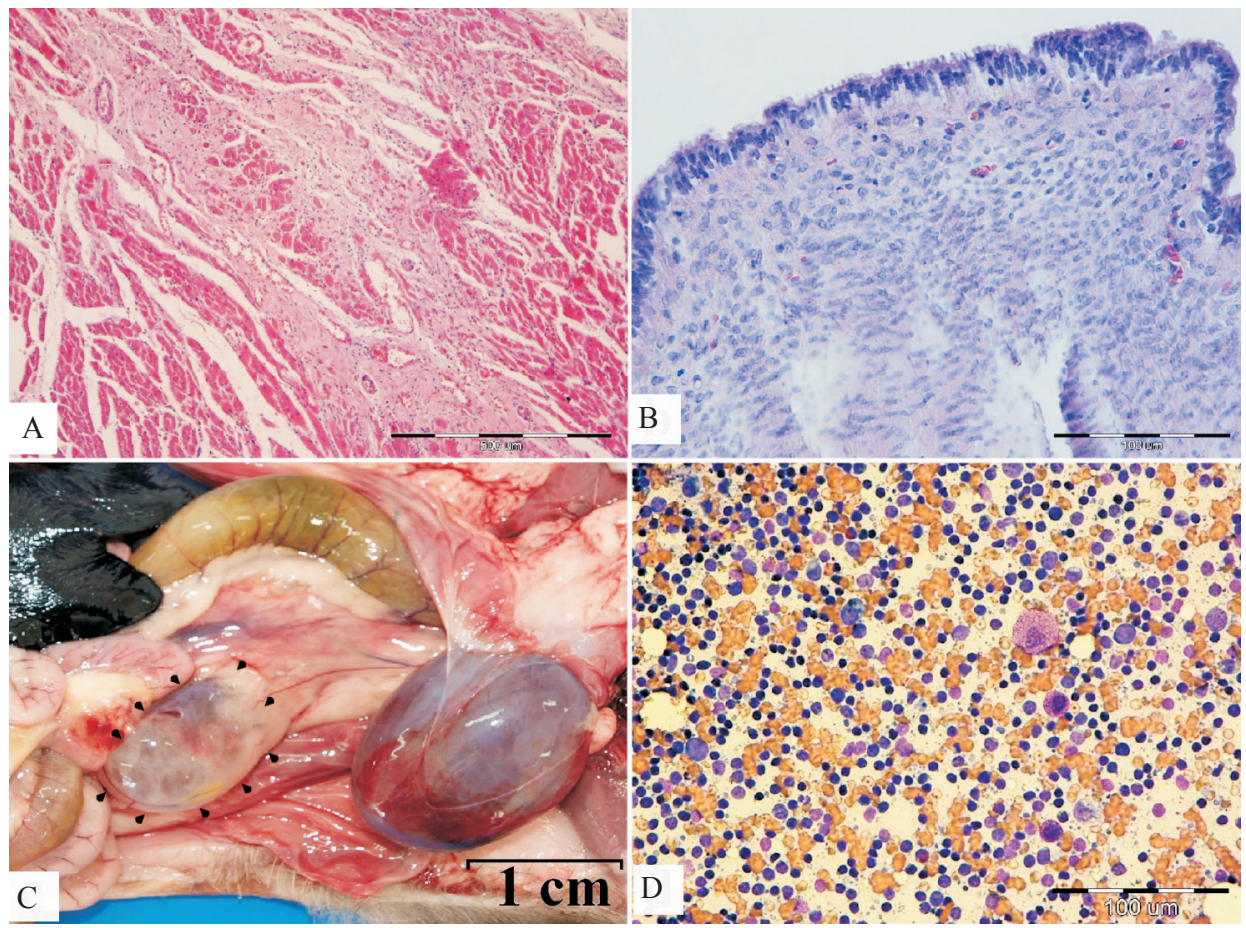

Fig. 4. Degenerative and miscellaneous disorders. A: Heart. Extensive myocardial fibrosis that caused heart failure. $H \& E, \times 100$. B: Uterus. Atrophy of the endometrium and submucosal uterine glands caused by hydrometra. H\&E, $\times 400$; C: Abdominal cavity. Polycystic kidney with large fluid filled cysts visible through the fibrous capsule (arrows). D: Aspirate of pancreatic lymph node. Reactive lymph node with diverse cell population consisting of small lymphocytes, lymphoblasts, plasma cells, monocytes, mastocytes and eosinophils. MGG, $\times 400$.

Interestingly, Sarcina organisms were found more numerously in ulcer free areas of the gastric mucosa, where the lamina propria submucosae and mucosa were severely infiltrated with lymphocytes (Fig. 3A). A single case of fibrinous and purulent peripancreatitis, severe necrotic ileitis, followed by disseminated intravascular coagulation development (1 case) and haemorrhagic jejunitis of unknown etiology (1 case, Fig. 2C) was included in this group of lesions. Within the haemolymphatic system, purulent splenitis of unknown cause (1 case), and pyogranulomatous lymphadenitis, probably caused by Pseudomonas luteola (1 case; Fig. 3C and 3D) were diagnosed. Bacterial culturing and molecular characterization was not performed, but the morphology of the bacteria 


\section{Huber et al.: Introduction to ferret pathology - 7 years of the Croatian experience}

and type of inflammation found microscopically, with a characteristic halo around the bacteria, were morphologically suggestive of infection with $P$. luteola. Purulent cystitis ( 1 case) was the only inflammatory lesion found in the urinary system. Inflammation in the reproductive system was recorded as a single case of haemorrhagic and purulent posthitis in a three year old ferret. Vegetative endocarditis of the left atrioventricular valve was the only pathology of inflammatory origin found in the heart, in a single case (Fig. 3E). In this case, etiology was diagnosed from histological findings of Gram-negative stained coccobacillus colonies present within the deposits of fibrin and pus. A single case of mononuclear dominantly lymphocytic inflammation was found in the liver. In the skin, sterile pyogranulomatous dermatitis and panniculitis was diagnosed in one case (Fig. 3F).

Microscopically, bacterial infections were the most common cause of inflammation (7 cases, $46.7 \%$ ), while viral infections were suspected, based on lymphocytic inflammation in a minority of cases ( 1 case, 6.6\%). Further immunochemical, microbiological or molecular investigations for precise determination of the microorganisms causing inflammation were not performed because the owners declined further investigation. For the same reason in an additional seven cases (46.7\%) the cause of inflammation remained unknown.

Degenerative disorders were found in five cases. The mean age of the affected ferrets was 7 years (Table 1). The disorders were diagnosed only in male animals (Table 1). In one case, the gender was unknown. The only damaged organ system in this category was the heart, where lesions were found in five cases: three cases of heart failure due to unknown mechanisms, dilated cardiomyopathy (1 case, Fig. 4A) and hypertrophic cardiomyopathy (1 case).

Miscellaneous disorders were found in 11 cases. The mean age of the affected ferrets was 5.7 years (Table 1). These disorders were diagnosed in six male ferrets and four females (Table 1). Disorders of the reproductive tract were hyperplasia of the endometrium of unknown cause (1 case), and hydrometra with resultant endometrial hypoplasia (1 case; Fig. 4B). In the urinary system, uretheral stenosis with subsequent hydronephros ( 1 case) and three cases of polycystic kidney disease (PKD, Fig. 4C) were diagnosed. In the haemolymphatic system, reactive hyperplasia of the lymph nodes (2 cases; Fig. 4D) and extramedullary haematopoiesis in the spleen (1 case) were found. Sebaceous gland hyperplasia of unknown cause was diagnosed in the skin of the mandible in one case. In the endocrine system, adrenal gland haematoma with osseous metaplasia (1 case) was found.

\section{Discussion}

From an historical point of view, ferrets were domesticated at nearly the same time as cats; however, so far they have not reached the same level of popularity. Nevertheless, 


\section{Huber et al.: Introduction to ferret pathology - 7 years of the Croatian experience}

ferrets continue to gain in popularity as companion animals, resulting in increased numbers of ferret patients in veterinary clinics worldwide (KEEBLE and MEREDITH, 2009; QUESENBERRY and CARPENTER, 2012). Subsequently, Croatian veterinarians need to understand the pathology of ferrets in order to efficiently diagnose, and subsequently treat diseases of this exotic carnivore species.

Since the vast majority of ferrets in this survey were middle to old aged, it was expected that neoplasia and degenerative disorders would be highly represented, as previously reported by KEEBLE and MEREDITH (2009) and QUESENBERRY and CARPENTER (2012).

All the lesions detected within the ferret population in our survey were previously described by BEACH and GREENWOOD (1993), RAKICH and LATIMER (2007), AMMERSBACH et al. (2008), MITCHELL and TULLY (2009), QUESENBERRY and CARPENTER (2012), MARTINEZ et al. (2012), HOHŠTETER et al. (2012), and BAUM et al. (2015). The only exception was a case of lymphocytic gastritis caused by Sarcinalike organisms, found in a three year old male ferret. Sarcina spp. are Gram-positive organisms found in cereal seeds, soil, mud and the stomachs of humans, with the ability to survive in a very low pH environment (RATUAPLI et al., 2013). Their tetrad morphology and size are characteristic enough to establish a diagnosis without further testing (LAMHIMLIN et al., 2011). This bacterium has been associated with abomasal bloat in livestock and as possible cause of gastric dilatation in dogs and horses (DeBAY et al., 1996; VATN et al., 2000; EDWARDS et al., 2008). As colonization of the gastric mucosa with this organism was seen on histology, accompanied by a strong inflammatory reaction, it is likely that gastritis in this ferret was caused by Sarcina sp. organisms. It is unlikely that these same organisms could have caused ulceration of the stomach. This suspicion is reinforced by the fact that in four other cases with ulcers in the stomach, no visible Sarcina organisms were found histologically. The Gram-positive rod-like bacteria were, in our opinion, a secondary infection in this particular case.

The most common pathology in our survey (more than $50 \%$ of cases) was neoplastic proliferation, with lymphoma being the most common diagnosis. Nowadays, tumours are the most common reason for presentation of ferrets to veterinarians (RAKICH and LATIMER, 2007; QUESENBERRY and CARPENTER, 2012). Due to their increased popularity as companion animals and the resulting prolonged life span of ferrets, the number of neoplastic diseases is in constant increase (MITCHELL and TULLY, 2009). Proposed etiologies for the development of neoplasia in ferrets are genetic predisposition, early neutering at 5 to 6 weeks of age, the lack of a natural photoperiod, exposure to carcinogenic substances, and infectious agents (MITCHELL and TULLY, 2009). Globally, it has been shown that lymphoma is the most common neoplasm diagnosed in ferrets (KEEBLE and MEREDITH, 2009; QUESENBERRY and CARPENTER, 2012). Although the exact etiology of lymphoma is still a mystery, Helicobacter mustelae infection has been 


\section{Huber et al.: Introduction to ferret pathology - 7 years of the Croatian experience}

described in association with gastric lymphoma (ERDMAN et al., 1997). In addition, retroviral involvement has been proposed (ERDMAN et al., 1996). These two proposed etiologies of gastric and systemic lymphoma were not investigated in this survey.

Apart from lymphoma, neoplasia also affected the endocrine system and skin in $29.4 \%$ of cases from our survey. Indeed, the endocrine system is the second most common site for tumour development in ferrets, after the haemolymphatic system, with pancreatic islet cell and adrenal gland tumours being the most common (QUESENBERRY and CARPENTER, 2012). Adrenal tumours in ferrets are specific for the fact that they secrete sex steroids rather than cortisol (MITCHELL and TULLY, 2009). The early age of spaying and neutering of ferrets has been associated with development of adrenal disease later in life (MITCHELL and TULLY, 2009). Namely, after neutering, an increase in concentrations of gonadotrophins occurs because of the loss of negative feedback (KEEBLE and MEREDITH, 2009). The increased concentration of gonadotrophins constantly produced in the adrenal cortex results in hyperplasia of the adrenal cortex, and eventually tumor development (KEEBLE and MEREDITH, 2009). As the ferret reproductive cycle is stimulated by light, ferrets that are kept indoors are simultaneously more stimulated by light (WAGNER et al., 2001; WAGNER et al., 2005). Hence, gonadotrophins are higher in ferrets kept indoors than outdoors (WAGNER et al., 2001; WAGNER et al., 2005). In addition, a hereditary syndrome with multiple endocrine neoplasia, like the human MEN syndrome, is postulated (KEEBLE and MEREDITH, 2009). In our survey, ferrets with adrenal tumours were mostly middle to old aged. Unfortunately, no data on spaying and neutering was provided.

Inflammation was mostly found in the digestive system, with gastric ulcers being the most common diagnosis. This finding was expected, as ferrets are extremely susceptible to stress-related gastric ulcers (QUESENBERRY and CARPENTER, 2012). In young, especially unstimulated and cage-bound ferrets, gastric ulceration due to foreign body ingestion is common (QUESENBERRY and CARPENTER, 2012). Gastric ulcers are an especially common finding in ferrets with other concurrent diseases, since disease presents a strong stress factor in these animals (QUESENBERRY and CARPENTER, 2012). In addition, application of non-steroidal anti-inflammatory and corticosteroid drugs can lead to ulcer development (KEEBLE and MEREDITH, 2009; QUESENBERRY and CARPENTER, 2012). History data and data on treatment drugs applied were scarce in our study, hence no conclusion on the cause of gastric ulcers could be drawn.

An interesting finding is that of Pseudomonas luteola-like pyogranuloma in the prescapular lymph node aspirate. Pseudomonas luteola is a motile aerobic Gram-negative rod that has been recently recognized as a cause of pyogranulomatous pleuropneumonia, with mediastinitis and panniculitis in ferrets (MARTINEZ et al., 2012; BAUM et al., 2015). $P$. luteola is frequently found in water, soil and humid environments (MARTINEZ et al., 2012). The primary pathogenic role of $P$. luteola, with a cutaneous route of entry into the 


\section{Huber et al.: Introduction to ferret pathology - 7 years of the Croatian experience}

organism, has been proposed in ferrets (MARTINEZ et al., 2012; BAUM et al., 2015). Due to the nature of ferret skin, traumatic wounds or poor husbandry conditions are generally required for bacterial skin disease to occur (KING et al., 1996). Indeed, ferrets are agile and lively animals, so they are prone to mechanical injury of the skin (RAKICH and LATIMER, 2007; QUESENBERRY and CARPENTER, 2012). In the case described in that study, the presented ferret was confirmed to have pyogranulomatous lymphadenitis of prescapular lymph node which fits into the "cutaneous entry route".

Degenerative disorders were, in our survey, only diagnosed in the heart. Generally, in ferrets, cardiomyopathy is a commonly described disease (WAGNER, 2009; QUESENBERRY and CARPENTER, 2012), however, the causes of this disease are not known (QUESENBERRY and CARPENTER, 2012). Signs such as lethargy, exercise intolerance, weight loss, coughing, cyanotic mucous membranes and ascites, which suggest cardiomyopathy (WAGNER, 2009), are mostly seen in middle aged ferrets. In our survey, the mean age of the ferrets diagnosed with degenerative disorders of the heart was 7 years, the highest mean age of all investigated classes of lesions.

In this study and globally, PKD was a common finding in the class of miscellaneous disorders. As in other animals, PKD in ferrets is characterized by numerous large cysts which destroy the surrounding kidney tissue, causing renal failure over time (JACKSON et al., 2008). The best characterized analog of PKD in a companion animal species is the polycystic kidney disease of Persian and Persian-type cats (BILLER et al., 1996). This type of PKD is caused by a nonfunctional protein involved in the regulation and coordination of kidney morphogenesis (THIVIERGE et al., 2006). As cats age, additional renal cysts occur, with renal failure onset at an average age of 7 years (BILLER et al., 1996). The feline PKD is inherited as an autosomal dominant trait, and it affects as much as one third of the mentioned breeds (JACKSON et al., 1996). As PKD is rare in ferrets, with few separate case reports, the inheritance of this disease has not been investigated (DILLBERGER, 1985; WILSON, 2004; JACKSON et al., 2008).

\section{Conclusion}

Despite the low case load obtained over the seven-year diagnostic period reviewed in this study, this analysis revealed that diseases found in the Croatian ferret population are very similar to those described in other countries in North America and Europe. As in other countries, the Croatian ferret population seems to suffer mostly from neoplastic diseases, with lymphoma as a leading disease. The most sensitive ferret organ systems to injury in our survey were the haemolymphatic system, the skin and the endocrine system. Infectious diseases were rarely found in the reviewed samples, probably due to the fact that Croatian ferrets are commonly vaccinated against parvovirosis and distemper. In addition, ferrets still represent a rare form of companion animal in Croatia, and are mostly 


\section{Huber et al.: Introduction to ferret pathology - 7 years of the Croatian experience}

kept solitary, without much contact with other ferrets and pets. This policy of keeping ferrets individually prevents the transmission of infectious diseases among animals. Due to the lack of official breeders in many European countries, as well as the higher demand for ferrets than the supply in pet shops, ferrets are often imported from other countries. This global trading scheme permits interchange of pathologies between different countries as well.

\section{Acknowledgements}

We would like to thank all pathologists from the Department of Veterinary Pathology, Faculty of Veterinary Medicine, University of Zagreb for their professional handling, processing and archiving of ferret samples.

\section{References}

AMMERSBACH, M., J. DELAY, J. L. CASWELL, D. A. SMITH, W. M. TAYLOR, D. BIENZLE (2008): Laboratory findings, histopathology, and immunophenotype of lymphoma in domestic ferrets. Vet. Pathol. 45, 663-673.

BAUM, B., B. RICHTER, M. REIFINGER, A. KLANG, C. FINNBERG, I. LONCARIC, J. SPERGSER, T. EISENBERG, F. KUNZEL, S. PREIS, N. PANTCHEV, B. RUTGEN, A. GUIJA DE ARESPACOCHAGA, M. HEWICKER-TRAUTWEIN (2015): Pyogranulomatous panniculitis in ferrets (Mustela putorius furo) with intralesional demonstration of Pseudomonas luteola. J. Comp. Pathol. 152, 114-118.

BEACH, J. E., B. GREENWOOD (1993): Spontaneous neoplasia in the ferret (Mustela putorius furo). J. Comp. Pathol. 108, 133-147.

Biller, D. S., S. P. DiBARTOlA, K. A. EATON, S. PFlueger, M. L. WELlMAN, M. J. RADIN (1996): Inheritance of polycystic kidney disease in Persian cats. J. Hered. 87, 1-5.

DeBAY, B. M., P. C. BLANCHARD, P. T. DURFEE (1996): Abomasal bloat associated with Sarcina-like bacteria in goat kids. J. Am. Vet. Med. Assoc. 209, 1468-1469.

DILLBERGER, J. E. (1985): Polycystic kidneys in a ferret. J. Am. Vet. Med. Assoc. 186, 74-75.

EDWARDS, G. T., N. G. A. WOODGER, A. M. BARLOW, S. J. BELL, D. G. HARWOOD, A. OTTER, A. R. WRIGHT (2008): Sarcina-like bacteria associated with bloat in young lambs and calves. Vet. Rec. 163, 391-393.

ERDMAN, S. E., P. J. KANKI, F. M. MOORE, S. A. BROWN, T. A. KAWASAKI, K. W. MIKULE, K. U. TRAVERS, S. F. BADYLAK, J. G. FOX (1996): Clusters of lymphoma in ferrets. Cancer. Invest. 14, 225-230.

ERDMAN, S. E., P. CORREA, L. A. COLEMAN, M. D. SCHRENZEL, X. LI, J. G. FOX (1997): Helicobacter mustelae-associated gastric MALT lymphoma in ferrets. Am. J. Pathol. 151, 273280. 
D. Huber et al.: Introduction to ferret pathology - 7 years of the Croatian experience

HOHŠTETER, M., O. SMOLEC, A. GUDAN KURILJ, I.-C. ŠOŠTARIĆ-ZUCKERMANN, I. BATA, Ž. GRABAREVIĆ (2012): Intratesticular benign peripheral nerve sheath tumour in a ferret (Mustela putorius furo). J. Small Anim. Pract. 53, 63-66.

JACKSON, C. N., A. B. ROGERS, K. J. MAURER, J. L. S. LOFGREN, J. G. FOX, R. P. MARINI (2008): Cystic renal disease in the domestic ferret. Comp. Med. 58, 161-167.

KEEBLE, E., A. MEREDITH (2009): BSAVA Manual of Rodents and Ferrets (Keeble, E., A. Meredith, Eds.), British Small Animal Veterinary Association, Waterwells, England.

KING, W. W., S. L. LEMARIE, R. S. VEAZEY, E. C. HODGIN (1996): Superficial spreading pyoderma and ulcerative dermatitis in a ferret. Vet. Dermatol. 7, 43-47.

LAM-HIMLIN, D., A. C. TSIATIS, E. MONTGOMERY, R. K. PAI, J. A. BROWN, M. RAZAVI, L. LAMPS, J. R. ESHLEMAN, B. BHAGAVAN, R. A. ANDERS (2011): Sarcina organisms in the gastrointestinal tract: a clinicopathologic and molecular study. Am. J. Surg. Pathol. 35, 1700-1705.

MARTINEZ, J., J. MARTORELL, M. L. ABARCA, A. OLVERA, A. RAMIS, L. WOODS, N. CHEVILLE, C. JUAN-SALLEZ, A. MOYA, A. RIERA, S. SOTO (2012): Pyogranulomatous pleuropneumonia and mediastinitis in ferrets (Mustela putorius furo) associated with Pseudomonas luteola infection. J. Comp. Pathol. 146, 4-10.

MitCHELL, M. A., T. N. TULLY (2009): Manual of Exotic Pet Practice (Mitchell, M. A., T. N. Tully, Eds.), Saunders Elsevier, Missouri, USA.

RAKICH, P. M., K. S. LATIMER (2007): Cytologic diagnosis of diseases of ferrets. Vet. Clin. Exot. Anim. 10, 61-78.

RATUAPLI, S. K., D. M. LAM-HIMLIN, R. I. HEIGH (2013): Sarcina ventriculi of the stomach: A case report. World. J. Gastroenterol. 19, 2282-2285.

QUESENBERRY, K. E., J. W. CARPENTER (2012): Ferrets, Rabbits and Rodents - Clinical Medicine and Surgery, $3^{\text {rd }}$ ed. (Quesenberry, K. E., J. W. Carpenter, Eds.), Elsevier Saunders, Missouri, USA.

Thivierge, C., A. KURBeGOVIC, M. COUillard, R. GUillaume, O. COTE, M. TRUDEL (2006): Overexpression of PKD1 causes polycystic kidney disease. Mol. Cell. Biol. 26, 1538-1548.

VALLI, V. E. O. T., M. KIUPEL, D. BIENZLE, R. D. WOOD (2016): Hematopoietic system. In: Jubb, Kennedy, and Palmer's Pathology of Domestic Animals Volume 3, $6^{\text {th }}$ ed. (Grant Maxie, M., Ed.), Elsevier, Missouri, USA, pp. 103-269.

VATN, S., G. GUNNES, K. NYBO, H. M. JUUL (2000): Possible involvement of Sarcina ventriculi in canine and equine acute gastric dilatation. Acta Vet. Scand. 41, 333-337.

WAGNER, R. A. (2009): Ferret cardiology. Vet. Clin. North. Am. Exot. Anim. Pract. 12, 115-134.

WAGNER, R. A., E. M. BAILEY, J. F. SCHNEIDER, J. W. OLIVER (2001): Leuprolide acetate treatment of adrenocortical disease in ferrets. J. Am. Vet. Med. Assoc. 218, 1272-1274. 
D. Huber et al.: Introduction to ferret pathology - 7 years of the Croatian experience

WAGNER, R. A., C. A. PICHE, W. JOHLE, J. W. OLIVER (2005): Clinical and endocrine responses to treatment with deslorelin acetate implants in ferrets with adrenocortical disease. Am. J. Vet. Res. 66, 910-914.

WILSON, P. D. (2004): Polycystic kidney disease. N. Eng. J. Med. 350, 151-164.

Received: 4 January 2016

Accepted: 4 April 2016

\section{HUBER, D., M. DVORNIK-GOJSAlić, B. ARTUKOVIĆ, A. BECK: Tvor (Mustela putorius furo) kao nova vrsta u patomorfološkoj dijagnostici - sedam godina iskustva u Hrvatskoj. Vet. arhiv 87, 317-331, 2017.}

\section{SAŽETAK}

Otkada je prije petnaestak godina tvor (Mustela putorius furo) prvi puta uveden kao kućni ljubimac na područje Republike Hrvatske, njegova popularnost i brojnost u neprestanom su porastu. Povećanje interesa za ovoga egzotičnog kućnog ljubimca popraćena je porastom interesa za njemu prilagođenom veterinarskom medicinskom skrbi. Kako bi se veterinarima praktičarima pružio uvid u najčešća patološka stanja do sada zabilježena u malobrojnoj populaciji u Republici Hrvatskoj, provedeno je retrospektivno istraživanje na 14 citoloških, 49 histopatoloških i 5 obdukcijskih arhivskih uzoraka podrijetlom od 68 jedinki tvorova pregledanih tijekom sedmogodišnjeg razdoblja u Zavodu za veterinarsku patologiju Veterinarskog fakulteta Sveučilišta u Zagrebu. Uzorci su u $60,7 \%$ slučajeva potjecali od mužjaka te u $39,3 \%$ od ženki. Srednja dob pregledane populacije iznosila je 5,1 godinu, s rasponom od 1 do 9 godina. Sve utvrđene dijagnoze svrstane su u kategorije: neoplazije $(n=37)$, upale $(n=15)$, degenerativni poremećaji $(n=5)$ te ostali poremećaji $(n=11)$. Organski sustavi u kojima su najčešće utvrđene lezije jesu hemolimfatični sustav, koža i endokrini sustav. U skupini neoplazmi, limfom se pokazao kao vodeća dijagnoza (12 slučajeva). Iako su tvorovi još uvijek rijetkost među ljubimcima u Hrvatskoj, učestalost lezija sumiranih u ovom istraživanju odgovara po učestalosti najčešće opisanim patološkim stanjima u populacijama tvorova drugdje u svijetu.

Ključne riječi: tvor, Mustela putorius furo, tumor, upala, degenerativne promjene, retrospektivno istraživanje 
